The Queer Greek Weird Wave 
Marios Psaras

\section{The Queer Greek Weird Wave}

Ethics, Politics and the Crisis of Meaning 
Marios Psaras

ISBN 978-3-319-40309-0 ISBN 978-3-319-40310-6 (eBook)
DOI 10.1007/978-3-319-40310-6

Library of Congress Control Number: 2016954569

(C) The Editor(s) (if applicable) and The Author(s) 2016

This work is subject to copyright. All rights are solely and exclusively licensed by the Publisher, whether the whole or part of the material is concerned, specifically the rights of translation, reprinting, reuse of illustrations, recitation, broadcasting, reproduction on microfilms or in any other physical way, and transmission or information storage and retrieval, electronic adaptation, computer software, or by similar or dissimilar methodology now known or hereafter developed.

The use of general descriptive names, registered names, trademarks, service marks, etc. in this publication does not imply, even in the absence of a specific statement, that such names are exempt from the relevant protective laws and regulations and therefore free for general use. The publisher, the authors and the editors are safe to assume that the advice and information in this book are believed to be true and accurate at the date of publication. Neither the publisher nor the authors or the editors give a warranty, express or implied, with respect to the material contained herein or for any errors or omissions that may have been made.

Printed on acid-free paper

This Palgrave Macmillan imprint is published by Springer Nature The registered company is Springer International Publishing AG The registered company address is: Gewerbestrasse 11, 6330 Cham, Switzerland 
To my family, the blood and the chosen 


\section{ACKNOWLEDGMENTS}

An earlier version of the material on Hardcore that appears in Chap. 1 was published as Marios Psaras, 'Soft Fantasies, Hardcore Realities: Greekness and the Death Drive in Dennis Iliades's Hardcore', in M. Photiou, T. Kazakopoulou and P. Phillis (eds), Contemporary Greek Film Cultures, Special Issue of Filmicon, 2, 2014, 133-155, and is reprinted here by kind permission of Filmicon. An earlier version of the material on Strella/A Woman's Way that appears in Chap. 3 was published as Marios Psaras, 'No Country for Old Faggots: Breaking with the Parental Home and Exploring Queer Utopias in Panos Koutras's Strella (2009)', in Tonia Kazakopoulou and Mikela Fotiou (eds), Contemporary Greek Film Cultures from 1990 to the Present (Oxford: Peter Lang, 2016), and is reprinted here by kind permission of Peter Lang.

I would like to express a deep gratitude to my mentors Robert Gillett and Libby Saxton for the many inspirational conversations about film, ethics and queerness, their astute remarks on my text and for always pushing for clarification. I am also grateful to Rosalind Galt and Lydia Papadimitriou for their helpful comments and insights on my doctoral thesis, from which this book was developed.

Finally, I am greatly indebted to a number of people that have surrounded me with unflagging support and encouragement-intellectual and personal - and without whom this book would not be possible: Stavros Makris, Christos Andreou, Alen Toplišek, Avgi Lilli, Maria Kountouri, Tonia Siamptani, Nandia Tomasidou, and of course my parents, Andreas and Pandelitsa Psaras. This book is dedicated to them. 


\section{Contents}

1 Introduction: The Meaning of the Crisis or the Crisis of Meaning

2 Hardcore: Of the Death Drive

3 Dogtooth: Of Narrativity

4 Strella: Of Queer Utopias

5 Attenberg: Of (Dis-)Orientation

6 Alps: Of Hauntology

7 Boy Eating the Bird's Food: Of Response-ability

8 Epilogue

Index 


\section{List of Figures}

Fig. 2.1 Blood-spattered Parthenon 36

Fig. 2.2 'Just like in "Beverly Hills"!' 44

Fig. 2.3 'Tonight Martha has an identity; name: whore, surname: whore, address: whore' $\quad 47$

Fig. 2.4 An ordinary home 'just like the rest of the world' 49

Fig. 2.5 National campiness $\quad 55$

Fig. 2.6 The returning image of the child $\quad 60$

$\begin{array}{lll}\text { Fig. 3.1 Sex as a mechanism } & 67\end{array}$

Fig. 3.2 The dominant perspective of the patriarch 68

Fig. 3.3 The grotesque, yet terrorizing space of the family home $\quad 72$

Fig. 3.4 'We have to be prepared ...'

Fig. 3.5 Beyond desire: sex as an act of kinship $\quad 80$

Fig. 3.6 Producing and performing familial time $\quad 86$

Fig. 4.1 Glamorizing the transgender face 94

Fig. 4.2 Mania Lempesi impersonating Melina Mercouri as Stella 103

Fig. 4.3 'You know what they are called ... transvestites' 109

$\begin{array}{ll}\text { Fig. 4.4 The ephemeral and the utopian } & 112\end{array}$

Fig. 4.5 Strella impersonating Maria Callas as Tosca 113

Fig. 4.6 Reframing the familial space 116

Fig. 5.1 De-eroticizing and reclaiming the naked female body 124

Fig. 5.2 Revisiting sexuality: perhaps the weirdest kiss in screen history 128

Fig. 5.3 Aligning the body with permissible objects of desire 141

Fig. 5.4 Reframing sex, formally and thematically 143

Fig. 5.5 Between life and death: confined to a decaying familial space 147

Fig. 5.6 Inhabiting the intensity of the queer moment 152

$\begin{array}{ll}\text { Fig. 6.1 Coercion and submission } & 156\end{array}$

Fig. 6.2 In the margin, yet still within the contours of the social 161 
Fig. 6.3 Emerging from the sea like a ghost approaching menacingly $\quad 164$

$\begin{array}{lll}\text { Fig. 6.4 Ghost among ghosts } & 165\end{array}$

Fig. 6.5 Stripped off any sense of identity, excluded from the realm of the social 176

$\begin{array}{lll}\text { Fig. 6.6 Our irreversible vulnerability to injury and loss } & 181\end{array}$

Fig. 7.1 Boy eating the bird's food 186

Fig. 7.2 The camera and the boy's physical proximity, yet emotional distance 199

Fig. 7.3 A nod to our perennial spectatorial position as 'Peeping Toms' 204

$\begin{array}{lll}\text { Fig. 7.4 Between victimhood and perpetration } & 207\end{array}$

Fig. 7.5 'What a beautiful voice.... You made me cry' 211

Fig. 7.6 Among the rubble, yet still surviving, still struggling 212 